\title{
ANALISIS PERBANDINGAN PERHITUNGAN METODE TRADISIONAL DENGAN METODE FULL COSTING DALAM MENENTUKAN LABA BERSIH \\ (Study Kasus: UD. Rizka Jaya Desa Dete Kecamatan Lape Kabupaten Sumbawa)
}

\author{
1Nurida Fitriani, ${ }^{2}$ Ahmad Jibrail, ${ }^{3}$ Danny Hambali \\ Program Studi Akuntansi Fakultas Ekonomi Dan Bisnis Universitas Teknologi Sumbawa \\ *Corresponding Author email: Ahmad.Jibrail@uts.ac.id, Denny.Hambali@uts.ac.id
}

\begin{tabular}{|c|c|}
\hline & Abstract \\
\hline $\begin{array}{l}\text { Diterima } \\
\text { Bulan September } \\
2019\end{array}$ & $\begin{array}{l}\text { Net income is one the of important elements that become the basis of decision making by } \\
\text { corporate management. The higher the profit earned then the more developed the } \\
\text { company. This study aims to (1) find out how the calculation of net income method of } \\
\text { company, (2) know how the calculation of net income method of full costing, and ( } 3 \text { ) } \\
\text { know how the comnutation of net income calculation between comnanv method with full }\end{array}$ \\
\hline $\begin{array}{l}\text { Diterbitkan } \\
\text { Bulan Oktober } \\
2019\end{array}$ & $\begin{array}{l}\text { know how the computation of net income calculation between company method with full } \\
\text { costing method. This research type is descriptive quantitative. Data was collected by } \\
\text { interview method. The result of research indicates that using traditional method, as } \\
\text { company used, makes company's net income lower than using costing method. It happens } \\
\text { because some costs were not calculated by the company. The company should use the } \\
\text { method of full costing in the calculation of net income because it describes the actual state }\end{array}$ \\
\hline $\begin{array}{l}\text { Keyword: Net } \\
\text { Income. Full } \\
\text { Costing Method, } \\
\text { Traditional } \\
\text { Method }\end{array}$ & of the company that calculates all costs incurred in the productions process. \\
\hline
\end{tabular}

\section{PENDAHULUAN}

Di era yang terus mengalami kemajuan dengan perkembangan teknologi yang begitu pesat, tentu sangat mempengaruhi segala hal dalam bidang kehidupan, salah satunya dalam bidang usaha yang juga mengalami perkembangan begitu pesat. Semakin berkembangnya suatu usaha maka perusahaan harus mampu menghasilkan produk yang berkualitas baik dengan harga yang wajar, sehingga dapat memberikan laba bersih bagi perusahaan dan produk yang dihasilkan dapat bersaing dengan produk lain yang sejenis.

Dengan terus berkembangnya usaha saat ini sedang gencar adanya pasar bebas atau lebih dikenal dengan MEA (Masyarakat Ekonomi ASEAN) yang mengakibatkan apabila suatu perusahaan tidak dapat menyaingi harga pasar yang dilakukan oleh para pesaing maka perusahaan tersebut akan dipastikan merugi. Dari sisi manfaatnya MEA memberikan akses pasar yang lebih luas dan serta menurunkan tarif perdagangan. Disisi lain, kerugian dari MEA adalah suatu Negara berpotensi menjadi merugi jika memiliki daya saing rendah. integrasi ekonomi pada akhirnya akan menciptakan skema persaingan antar Negara yang tergabung dalam integrasi ekonomi. Persaingan ini pada akhirnya menuntut setiap Negara untuk meningkatkan daya saingnya yang disebut precompetitive effect melalui tiga cara: pemanfaatan teknologi, penetapan harga jual, dan peningkatan ekspor. Ketiga cara tersebut bersinggungan langsung dengan kebijakan pemerintah, dimana pemerintah memainkan peran signifikan dalam mengeluarkan kebijakan yang mendukung peningkatan daya saing. MEA mempengaruhi kebijakan industry manufaktur Indonesia yaitu kebijakan pemanfaatan teknologi, penetapan harga jual dan meningkatkan ekspor (Sudarma, 2016).

Perkembangan usaha yang begitu pesat terus mengalami kemajuan baik skala mikro maupun makro. Usaha Kecil Menengah (UKM) sebagai penggerak roda ekonomi berskala mikro mulai berkembang dan ikut bersaing dalam menghasilkan suatu produk demi mendapatkan laba. Melalui UKM, pemerintah juga berupaya memperluas lapangan kerja agar angka pengangguran dan kemiskinan di Indoesia berkurang (Firmansyah, 2015).

Berkaitan dengan pengembangan usaha, tentu saja industri manapun ingin mencapai sasaran yang telah ditetapkan. Dengan kata lain mereka ingin mencapai keberhasilan usaha. Faktor yang merupakan tujuan yang kritis dan menjadi ukuran dari keberhasilan suatu perusahaan adalah adalah laba. Keberhasilan usaha merupakan utama dari sebuah perusahaan dimana segala aktivitas yang ada didalamnya ditujukan untuk mencapai suatu keberhasilan (Masyukri, 2014).

Menentukan harga pokok suatu produk sama halnya dengan menghitung berapa biaya yang diserap oleh produk tersebut. Biaya tersebut meliputi banyaknya biaya yang dikeluarkan untuk bahan baku langsung, tenaga kerja langsung, dan biaya overhead perusahaan. Ketiga hal tersebut perlu diperhatikan dan dicatat sesuai dengan 
penggolongan dan pengalokasiannya, dan mempermudah penentuan laba yang diinginkan perusahaan. Pihak perusahan harus cerdas dalam mengambil keputusan berapa jumlah harga pokok produksi yang dipatok dengan menimbang banyaknya biaya yang dikeluarkan serta laba yang ingin dicapai perusahaan. Laba yang dihasilkan dapat membantu perusahaan dalam mengetahui seberapa kontribusi laba yang dihasilkan masingmasing produk terhadap perusahaan (Aprilia, 2015).

Menurut penelitian sebelumnya yang dilakukan oleh Aprilia (2015) yang berjudul Analisis Penentuan HPP (Harga Pokok Produksi) Mebel dengan Metode Full Costing dalam Pencapaian Laba Perusahaan di CV. Rajawali Perkasa Furniture Juwana. Dari hasil penelitian dan evaluasi yang telah dilakukan terhadap perusahaan mebel CV Rajawali Perkasa Furniture mendapatkan hasil bahwa tingginya harga pokok produksi yang dibebankan perusahaan menyebabkan kontribusi laba yang dicapai perusahaan hanya sebesar 9,07\% dan belum mencapai target laba sebesar $15 \%$. Sedangkan harga pokok produksi dengan metode full costing lebih rendah sehingga kontribusi laba yang diperoleh lebih besar yaitu sebesar 31,32\%. Selanjutnya harga pokok produksi untuk produk Devon Teak Haast Bar Table 1500 terdapat selisih sebesar Rp 74.793,96, harga pokok produksi yang dipatok perusahaan juga lebih tinggi dibanding dengan harga pokok produksi dengan metode full costing sehingga laba yang diperoleh perusahaan sebesar 9,06\% dan tidak bisa mencapai target laba sebesar $15 \%$. Sedangkan laba yang diperoleh dengan metode full costing sebesar 12,51\%. Dengan menggunakan metode full costing, pencapaian laba produk kursi Devon Teak Jackson Easy Chair Shadow Grey lebih memungkinkan untuk memenuhi target laba perusahaan dibandingkan dari capaian laba produk meja Devon Teak Haast Bar Table 1500.

UD. Rizka Jaya merupakan salah satu industry meubel yang terdapat di Kecamatan Lape Kabupaten Sumbawa yang telah berdiri sejak 5 tahun yang lalu dan memiliki omzet yang besar untuk setiap bulannya. Selama ini, UD. Rizka Jaya dalam menghitung keuntungan atau laba bersih perusahaan masih menggunakan metode yang relative sangat sederhana dan belum menerapkan perhitungan sesuai dengan kaidah akuntansi biaya. UD Rizka Jaya belum memasuskkan semua unsur biaya yang dikeluarkan dalam proses produksi secara terperinci. Selain itu juga industry mebeul ini belum menghitung biaya overhead secara terperinci dan belum memperhatikan seluruh biayabiayaoverhead pabrik, serta belum menggunakan metodedalam menentukan laba bersih, terdapat juga beberapa biaya yang seharusnya dalam kaidah akuntansi biaya dinyatakan sebagai beban, namun tidak dinyatakan oleh perusahaan. Oleh karena itu penelitian ini menggunakan metode full costing karena metode ini merupakan metode perhitungan yang membebankan seluruh unsur biaya baik yang bersifat tetap maupun variable kedalam produk. Hal ini lah yang menjadi landasan dalam menggunakan metode full costing karena pentingnya perusahaan untuk menghitung semua biaya yang dikeluarkan untuk menghasilkan produk yang merupakan dasar dalam penentuan harga dan sebagai landasan dalam penentuan laba bersih. Serta diharapkan agar dapat membantu industri tersebut khususnya bagi pihak manajemen.

Berdasarkan latar belakang diatas, maka judul penelitian ini adalah "Analisis Perbandingan Perhitungan Metode Tradisional dengan Metode Full Costing untuk Penentuan Laba Bersih". Dengan mengambil study kasus pada UD. Rizka Jaya Mebel Desa Lape Kecamatan Lape Kabupaten Sumbawa.

\section{LANDASAN TEORI}

\section{Akuntansi Biaya}

Akuntansi biaya merupakan salah satu bagian dari bidang akuntansi meliputi kegiatan proses pencatatan dan monitoring seluruh aktifitas biaya dan menyajikan informasi tersebut dalam satu laporan (Rinaldi, 2015).

\section{Biaya Produksi}

Biaya Manfuacture atau biaya produksi atau biaya pabrik biasanya didefinisikan sebagai jumlah dari tiga elemen biaya: bahan baku langsung, tenaga kerja langsung, dan overhead pabrik. Bahan baku langsung dan tenaga kerja langsung keduanya disebut biaya utama (prime cost). Tenaga kerja langsung dan overhead pabrik, keduanya disebut biaya konvensional. (Carteer, 2005:40)

\section{Harga Pokok Produksi}

Adapun unsur-unsur harga pokok produksi adalah bahan Baku langsung, tenaga kerja langsung, Dan overhead pabrik.

\section{Metode Full Costing}

Mengaitkan sebagian atau seluruh total biaya manufaktur tetap ke unit-unit produk, biaya ini kemdian dibebankan sebagai bagian dari nilai harga pokok penjualan di laporan laba rugi ketika unit yang bersangkutan dijual. Alternative ini disebut dengan perhitungan biaya absorpsi penuh (full absorption costing) dan diharuskan untuk pelaporan menurut prinsip Akuntansi yang Berlaku Umum (GAAP) dan pajak penghasilan (Carteer, 2005).

\section{Laba Bersih}

Laba adalah selisih lebih pendapatan atas beban sehubungan dengan kegiatan usaha. Apabila beban lebih besar dari pendapatan, selisihnya disebut rugi.Laba atau rugi merupakan hasil perhitungan secara periodik (berkala).Penetapan 
laba secara periodik merupakan perhatian yang serius. (Soemarso, 2005:230)

\section{METODE PENELITIAN}

\section{Jenis Penelitian}

Deskriptif kuantitatif adalah analisis data yang diukur dalam skala numerik atau angka, analisis kuantitatif disiniyang dilakukan adalah dengan perhitungan.

\section{Tempat dan Waktu Penelitian}

Penelitian ini dilakukan di UD. Rizka Jaya Meubel yang terletak di Kecamatan Lape Kabupaten Sumbawa. Waktu penilitian dimulai pada bulan Oktober 2017 - Februari 2018.

\section{Sumber Data}

Data Primer yaitu data yang diperoleh langsung dari objek yang akan diteliti berupa hasil wawancara langsung dengan karyawan dan juga pimpinan UD. Rizka Jaya Mebel. Data Skunder merupakan data yang didapat melalui perantara seperti buku, kepustakaan dan informasi lainnya.

\section{Teknik Pengumpulan Data}

Wawancara. Wawancara dilakukan dengan bertanya langsung kepada pemilik mengenaikeuangan perusahaan, pengeluaran serta pemasukan perusahaan dalam proses produksi dan bahan-bahan serta alat yang digunakan perusahaan. Observasi. Observasi dilakukan untuk mengumpulkan data dengan cara mengamati langsung objek yang akan diteliti. Dalam observasi peneliti melihat secara langsung keadaan lingkungan kerja, bahan yang digunakan, pengolahan bahan baku, produktivitas tenaga kerja, peralatan yang digunakan dalam memproduksi, bahan-bahan penolong yang digunakan dan lainlain.

\section{Teknik Analisis Data}

Langkah-langkah yang dilakukan untuk menjawab rumusan masalah adalah; (1) Mendeskripsikan penghitungan harga pokok produksi dan penentuan laba operasi perusahaan dengan menjabarkan biaya-biaya produksi yang dikeluarkan oleh perusahaan dalam suatu periode tertentu; (2) Menentukan prosedur penentuan harga pokok menurut metode full costing dengan cara (a) Mengumpulkan data produksi dalam periode tertentu dan mengumpulkan biaya bahan baku, biaya tenaga kerja, dan biaya overhead pabrik periode tertentu untuk menyususn laporan produksi, (b) Mendeskripsikan dan melakukan penghitungan harga pokok produksi sebagai metode full costing: Biaya Bahan Baku (xxx) + Biaya TKL (xxx) + Biaya Overhead Pabrik $(\mathrm{xxx})=$ Total Biaya Produksi (xxx), (c) Diasumsikan bahwa finish good awal dan finish good akhir bernilai sama; (3) Melakukan penghitungan untuk menentukan laba bersih

\begin{tabular}{|c|c|c|}
\hline Penjualan & $\mathrm{xxx}$ & \\
\hline Harga Pokok Penjualan & $(\mathrm{xxx})$ & \\
\hline Laba Kotor & & $\mathrm{Xxx}$ \\
\hline Beban administratsi $\mathrm{xxx}$ & & \\
\hline Beban operasional $\mathrm{xxx}$ & & \\
\hline Beban Pendanaan & $\mathrm{XXX}$ & \\
\hline Beban pemasaran & $\mathrm{xxx}$ & $\underline{(\mathrm{xxx})}$ \\
\hline Laba Operasional & & $\mathrm{xxx}$ \\
\hline Beban Pajak Penghasila & $5 \%)$ & $(\mathrm{xxx})$ \\
\hline Laba Bersih & & $\mathbf{X X X}$ \\
\hline
\end{tabular}

(4) Membandingkan procedure perhitungan metode yang diterapkan oleh perusahaan (metode tradisional) dengan metode full costing sesuai teori; (5) Melakukan analisis terhadap perbandingan tersebut untuk mendapatkan hasil apakah ada perbedaan dengan teori; (6) menarik kesimpulan.

\section{HASIL DAN PEMBAHASAN}

\section{Sejarah Singkat Pembahasan}

UD. Rizka Jaya merupakan salah satu usaha kecil menengah yang telah berdiri sejak 5 tahun lalu yakni pada tahun 2012 yang didirikan oleh Bapak Agus Wardi. UD. Rizka Jaya terletak di Dusun Bukit Tinggi RT.01/RW.013 Desa Dete Kecamatan Lape Kabupaten Sumbawa.

Berikut merupakan data penjualan yang dilakukan oleh UD. Rizka Jaya selama tahun 2017:

Table 4.1. Penjualan Pada Tahun 2017

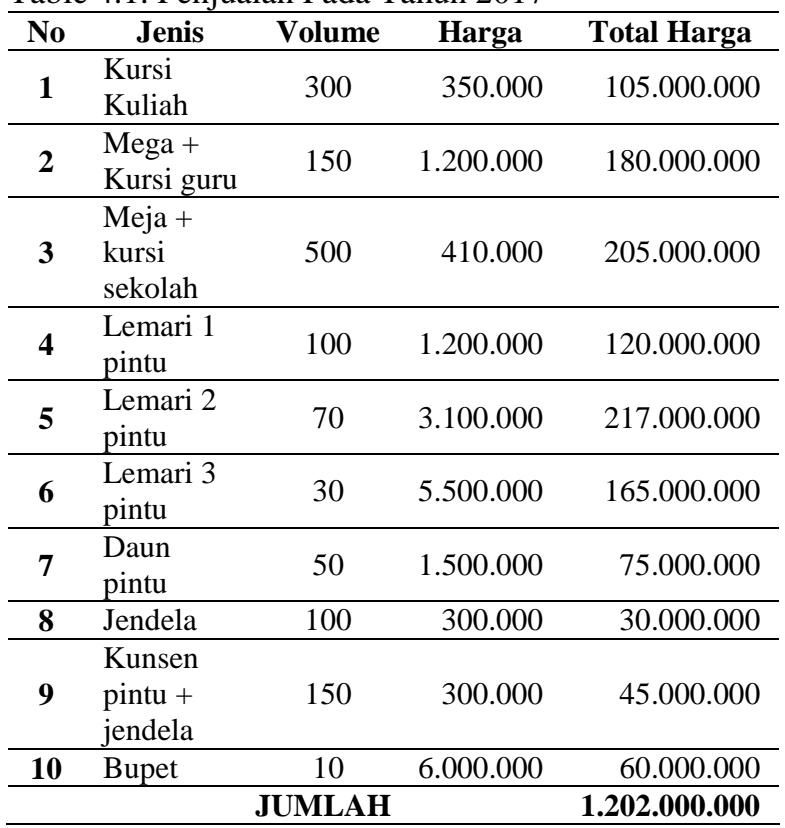

Sumber: UD. Rizka Jaya

\section{Identifikasi Biaya}

1. Identifikasi Biaya Seluruh Produk

$$
\text { a. Badan Baku }
$$

Untuk sekali produksi industry ini dapat memproduksi beberapa jenis produk. Selama tahun 2017 atau selama satu periode industry meubel ini sudah memproduksi ratusan produk. Itu mengapa 
bahan baku yang digunakan pun dapat dikatakan dalam skala besar yakni sebanyak 55 kubik kayu dengan harga perkubik yakni Rp 4.000.000.

Table 4.2. Biaya Bahan Baku Langsung Produk Meubel

\begin{tabular}{cccc}
\hline Jenis & $\begin{array}{c}\text { Volume } \\
\left(\mathbf{m}^{\mathbf{3}}\right)\end{array}$ & $\begin{array}{c}\text { Harga } \\
\text { Satuan/m }\end{array}$ & $\begin{array}{c}\text { Jumlah } \\
(\mathbf{R p})\end{array}$ \\
\hline Kayu jati & 55 & 4.000 .000 & 220.000 .000 \\
\hline
\end{tabular}

Sumber: UD. Rizka Jaya

\section{b. Biaya Tenaga Kerja Langsung}

Seluruh tenaga kerja yang ada di industry ini merupakan tenaga kerja langsung yakni sebanyak 8 orang tenaga kerja yang melakukan seluruh proses produksi. Jam kerja untuk setiap harinya yakni 8 jam per hari. Pekerja diberikan gaji sesuai Dungan produk yang dihasilkan, dari masingmasing produk memiliki biaya tenaga kerja yang berbeda-beda. Berikut adalah daftar biaya tenaga kerja yang dikeluarkan untuk masing-masing produk.

Table 4.3. Biaya Tenaga Kerja Langsung

\begin{tabular}{|c|c|c|c|c|}
\hline No & Jenis & Volume & Harga & $\begin{array}{c}\text { Total } \\
\text { Harga } \\
\end{array}$ \\
\hline 1 & Bupet & 10 & 800.000 & 8.000 .000 \\
\hline 2 & Jendela & 100 & 30.000 & 3.000 .000 \\
\hline 3 & Kunsen & 150 & 100.000 & 1.500 .000 \\
\hline 4 & $\begin{array}{l}\text { Kursi } \\
\text { Kuliah }\end{array}$ & 300 & 60.000 & 18.000 .000 \\
\hline 5 & $\begin{array}{l}\text { Kursi + } \\
\text { Meja }\end{array}$ & 500 & 70.000 & 35.000 .000 \\
\hline 6 & $\begin{array}{l}\text { Lemari } 1 \\
\text { pintu }\end{array}$ & 200 & 400.000 & 80.000 .000 \\
\hline 7 & $\begin{array}{l}\text { Lemari } 2 \\
\text { pintu }\end{array}$ & 70 & 500.000 & 35.000 .000 \\
\hline 8 & $\begin{array}{l}\text { Lemari } 3 \\
\text { pintu }\end{array}$ & 30 & 600.000 & 18.000 .000 \\
\hline 9 & $\begin{array}{l}\text { Meja + } \\
\text { kursi guru }\end{array}$ & 150 & 150.000 & 22.500 .000 \\
\hline 10 & Pintu & $\begin{array}{c}50 \\
\text { JUMLAH }\end{array}$ & 200.000 & $\begin{array}{r}10.000 .000 \\
\mathbf{2 3 1 . 0 0 0 . 0 0 0}\end{array}$ \\
\hline
\end{tabular}

Sumber: UD. Rizka Jaya

Selama tahun 2017, perusahaan mengeluarkan gaji karyawan sebesar Rp231.000.000/tahun Sehingga setiap karyawan mendapatkan gaji sebesar Rp28.875.000/tahun atau selama tahun 2017.

c. Biaya Overhead Pabrik

1. Biaya Listrik

Listrik tentu merupakan salah satu hal yang paling penting dan sangat dibutuhkan dalam proses produksi. Hampir seluruh mesin yang digunakan memanfaatkan tenaga listrik yang sudah tentu listrik memiliki peran penting dalam proses produksi. Biaya yang dikeluarkan oleh perusahaan dalam hal ini adalah sebesar Rp1.300.000/bulan untuk pembayaran listrik.
2. Biaya Bahan Baku Tidak Langsung

Bahan baku tidak langsung atau bahan baku penolong merupakan salah satu penunjang dalam pembuatan produk di industry meubel. dengan bahan baku penolong maka bentuk serta jenis produk dapat diketahui. Misalkan untuk membuat sebuah meja membutuhkan lem sebagai perekat dan pintu membutuhkan engsel, serta beberapa bahan lainnya.

Table 4.4. Biaya Bahan Baku Tidak Langsung

\begin{tabular}{|c|c|c|c|c|}
\hline No & Jenis & Volume & $\begin{array}{c}\text { Harga } \\
\text { per } \\
\text { item }\end{array}$ & $\begin{array}{c}\text { Total } \\
\text { Harga }\end{array}$ \\
\hline 1 & $\begin{array}{l}\text { Kaca } \\
\text { rayben }\end{array}$ & 20 lembar & 250.000 & 5.000 .000 \\
\hline 2 & $\begin{array}{l}\text { Kaca } \\
\text { Rasa }\end{array}$ & 10 lembar & 225.000 & 2.250 .000 \\
\hline 3 & Triplek & 150 lembar & 60.000 & 9.000 .000 \\
\hline 4 & Pelitur & 288 kaleng & 60.000 & 17.280 .000 \\
\hline 5 & Tinner & 600 kaleng & 115.000 & 69.000 .000 \\
\hline 6 & $\begin{array}{l}\text { Sending } \\
\text { seller }\end{array}$ & 1.000 kaleng & 65.000 & 65.000 .000 \\
\hline 7 & $\begin{array}{l}\text { Clear } \\
\text { glossy }\end{array}$ & 1.000 kaleng & 65.000 & 65.000 .000 \\
\hline 8 & $\begin{array}{l}\text { Paku } 6 \\
\mathrm{~cm}\end{array}$ & $10 \mathrm{~kg}$ & 15.000 & 150.000 \\
\hline 9 & $\begin{array}{l}\text { Paku } 5 \\
\mathrm{~cm}\end{array}$ & $10 \mathrm{~kg}$ & 15.000 & 150.000 \\
\hline 10 & $\begin{array}{l}\text { Paku } 4 \\
\mathrm{~cm}\end{array}$ & $10 \mathrm{~kg}$ & 15.000 & 150.000 \\
\hline 11 & $\begin{array}{l}\text { Engsel } \\
\text { pintu }\end{array}$ & 70 kotak & 50.000 & 3.500 .000 \\
\hline 12 & Lem & 200 dus & 350.000 & 70.000 .000 \\
\hline 13 & $\begin{array}{l}\text { Kunci } \\
\text { pintu }\end{array}$ & 50 buah & 250.000 & 12.500 .000 \\
\hline 14 & $\begin{array}{l}\text { Grendel } \\
\text { pintu }\end{array}$ & 50 buah & 12.000 & 600.000 \\
\hline 15 & $\begin{array}{l}\text { Grendel } \\
\text { jendela }\end{array}$ & 50 buah & 7.000 & 350.000 \\
\hline 16 & $\begin{array}{l}\text { Kunci } \\
\text { lemari } 1 \\
\text { pintu }\end{array}$ & 100 buah & 20.000 & 2.000 .000 \\
\hline 17 & $\begin{array}{l}\text { Kunci } \\
\text { lemari } 2 \\
\text { pintu }\end{array}$ & 140 buah & 20.000 & 2.800 .000 \\
\hline 18 & $\begin{array}{l}\text { Kunci } \\
\text { lemari } 3 \\
\text { pintu }\end{array}$ & 90 buah & 20.000 & 1.800 .000 \\
\hline 19 & $\begin{array}{l}\text { Kunci } \\
\text { bupet }\end{array}$ & 50 buah & 20.000 & 1.000 .000 \\
\hline \multirow[t]{2}{*}{20} & $\begin{array}{l}\text { Engsel } \\
\text { lemari }\end{array}$ & 300 kotak & 12.000 & 3.600 .000 \\
\hline & & JUMLAH & & 331.130.000 \\
\hline
\end{tabular}

3. Biaya depresiasi mesin, bangunan dan kendaraan

Bangunan yang digunakan industry ini dalam proses produksi adalah semi permanen dengan biaya yang dikeluarkan Rp10.000.000 dengan umur ekonomis 10 
tahun. selain bangunan juga terdapat beberapa mesin yang digunakan secara langsung dalam proses produksi. Berikut adalah penyusutan mesin, bangunan pada tahun 2017.

Table 4.5. Biaya Penyusutan

\begin{tabular}{llcccr}
\hline No. & \multicolumn{1}{c}{ Jenis } & $\begin{array}{c}\text { Harga } \\
\text { Perolehan } \\
\text { (Rp) }\end{array}$ & $\begin{array}{c}\text { Umur } \\
\text { Ekonomis } \\
\text { (Tahun) }\end{array}$ & $\begin{array}{c}\text { Nilai } \\
\text { Residu }\end{array}$ & $\begin{array}{c}\text { Biaya } \\
\text { Penyusutan }\end{array}$ \\
\hline 1. & Gedung & 10.000 .000 & 10 & 1.000 .000 & 900.000 \\
2. & Mesin ketam & 27.000 .000 & 10 & 2.700 .000 & 2.430 .000 \\
& duduk & & & & \\
3. & Mesin pahat & 6.000 .000 & 10 & 600.000 & 540.000 \\
4. & Mesin jigsaw & 35.000 .000 & 10 & 3.500 .000 & 3.150 .000 \\
5. & Mesin gergaji & 37.000 .000 & 10 & 3.700 .000 & 3.330 .000 \\
& pita & & & & \\
6. & Mesin press & 42.000 .000 & 10 & 4.200 .000 & 3.780 .000 \\
7. & Mesin siku & 27.000 .000 & 10 & 2.700 .000 & 2.430 .000 \\
8. & Mesin stoling & 37.000 .000 & 10 & 3.700 .000 & 3.330 .000 \\
9. & Mesin asa & 12.000 .000 & 10 & 1.200 .000 & 1.080 .000 \\
& pisau planer & & & & \\
10. & Mesin & 3.500 .000 & 10 & 350.000 & 315.000 \\
& Kompresor & & & & \\
11. & Pickup & 130.000 .000 & 10 & 13.000 .000 & 11.700 .000 \\
& (Kendaraan) & & & & \\
& & Jumlah & & & \\
\hline
\end{tabular}

Sumber: Olah Data

4. Biaya Pemeliharaan dan Perawatan

Mesin memiliki biaya peralatan yang kadang tidak menentu dan tidak tetap untuk sistem perawatannya. Akan tetapi, secara keseluruhan untuk tahun 2017 biaya perawatan dan pemeliharaan yang dikeluarkan untuk mesin adalah sebesar Rp5.500.000 dan untuk bangunan adalah Rp2.000.000.

5. Biaya Transportasi

Akumulasi untuk biaya transportasi perusahaan selama satu tahun atau dalam tahun 2017 adalah sebesar Rp15.000.000

6. Biaya Overhead Pabrik

Berikut merupakan total biaya overhead pabrik perusahaan selama tahun 2017.

Table 4.6. Biaya Overhead Pabrik Variabel

\begin{tabular}{lr}
\hline \multicolumn{1}{c}{ Overhead Pabrik Variabel } & \multicolumn{1}{c}{ Jumlah } \\
\hline Biaya Bahan Baku Penolong & 331.130 .000 \\
Biya Listrik & 15.600 .000 \\
Biaya perawatan mesin & 5.500 .000 \\
Biaya perawatan bangunan & 2.000 .000 \\
Biaya Transportasi & 15.000 .000 \\
\hline \multicolumn{1}{c}{ Jumlah } & $\mathbf{3 6 9 . 2 3 0 . 0 0 0}$ \\
\hline
\end{tabular}

Sumber: Olah Data

Table 4.7. Biaya Overhead Pabrik Tetap

\begin{tabular}{cc}
\hline Overhead Pabrik Tetap & Jumlah \\
\hline Biaya penyusutan & 33.985 .000
\end{tabular}

$\frac{\text { Jumla }}{\text { Sumber: Olah Data }}$

33.985.000

\section{Identifikasi Biaya Per Unit}

Pada tahun 2017 terdapat banyak produk yang dihasilkan perusahaan seperti meja, kursi lemari, dan beberapa produk lainya lagi. Dari banyaknya produk yang diproduksi, terdapat dua jenis produk yang berbeda akan tetapi, memiliki harga jual yang sama. Yakni satu set kursi dan meja guru serta lemari 1 pintu.

Table 4.8. Presentase Proporsi Produk

\begin{tabular}{lcrccc}
\hline Nama Produk & $\begin{array}{c}\text { Jumlah } \\
\text { Pesanan }\end{array}$ & Nilai Jual & $\begin{array}{c}\text { Total Nilai } \\
\text { Jual }\end{array}$ & $\begin{array}{c}\text { Proporsi } \\
\text { Produk }\end{array}$ & $\begin{array}{c}\text { Proporsi } \\
\text { per Unit }\end{array}$ \\
\hline Kursi Kuliah & 300 & 350.000 & 105.000 .000 & $8,73 \%$ & $0,02 \%$ \\
Meja + Kursi & $150 \mathrm{set}$ & 1.200 .000 & 180.000 .000 & $14,97 \%$ & $0,09 \%$ \\
Guru & & & & & \\
Meja+Kursi & $500 \mathrm{set}$ & 410.000 & 205.000 .000 & $17,05 \%$ & $0,03 \%$ \\
Sekolah & & & & & \\
Lemari 1 Pintu & 100 & 1.200 .000 & 120.000 .000 & $9,98 \%$ & $0,09 \%$ \\
Lemari 2 Pintu & 70 & 3.100 .000 & 217.000 .000 & $18,05 \%$ & $0,25 \%$ \\
Lemari 3 Pintu & 30 & 5.500 .000 & 165.000 .000 & $13,72 \%$ & $0,45 \%$ \\
Daun Pintu & 50 & 1.500 .000 & 75.000 .000 & $6,23 \%$ & $0,12 \%$ \\
Jendela & 100 & 300.000 & 30.000 .000 & $2,49 \%$ & $0,02 \%$ \\
Kunsen & 150 & 300.000 & 45.000 .000 & $3,74 \%$ & $0,02 \%$ \\
Bupet & 10 & 6.000 .000 & 60.000 .000 & $4,99 \%$ & $0,49 \%$ \\
Jumlah & $\mathbf{1 . 4 6 0}$ & $\mathbf{1 9 . 8 6 0 . 0 0 0}$ & $\mathbf{1 . 2 0 2 . 0 0 0 . 0 0 0}$ & & \\
\hline
\end{tabular}

Sumber: UD. Rizka Jaya \& Olah Data

a. Biaya Bahan Baku

Bahan baku yang digunakan oleh perusahaan merupakan kayu jati. Berikut adalah rincian bahan baku yang dibutuhkan untuk masing-masing unit produk.

Table 4.9. Biaya Bahan Baku dalam Pemakaian $1 \mathrm{~m}^{3}$

\begin{tabular}{|c|c|c|c|c|c|}
\hline Produk & $\begin{array}{c}\text { Unit } \\
\text { Pesanan }\end{array}$ & $\begin{array}{c}\text { Pemakaian } \\
\text { untuk } 1 \mathrm{~m}^{3} \\
\text { kayu }\end{array}$ & $\begin{array}{c}\text { Jumlah } \\
\text { pemakaian }\end{array}$ & Harga per $\mathbf{m}^{3}$ & Total \\
\hline Kursi Kuliah & 300 & 45 & $6,67 \mathrm{~m}^{3}$ & 4.000 .000 & 26.680 .000 \\
\hline Meja Guru & 150 & 35 & $4,28 \mathrm{~m}^{3}$ & 4.000 .000 & 30.440 .000 \\
\hline Kursi Guru & 150 & 45 & $3,33 \mathrm{~m}^{3}$ & 4.000 .000 & 13.320 .000 \\
\hline Meja & 500 & 40 & $12,5 \mathrm{~m}^{3}$ & 4.000 .000 & 50.000 .000 \\
\hline $\begin{array}{l}\text { Kursi } \\
\text { Sekolah }\end{array}$ & 500 & 50 & $10 \mathrm{~m}^{3}$ & 4.000 .000 & 40.000 .000 \\
\hline $\begin{array}{l}\text { Lemari } 1 \\
\text { Pintu }\end{array}$ & 100 & 20 & $5 \mathrm{~m}^{3}$ & 4.000 .000 & 20.000 .000 \\
\hline $\begin{array}{l}\text { Lemari } 2 \\
\text { Pintu }\end{array}$ & 70 & 17 & $4,1 \mathrm{~m}^{3}$ & 4.000 .000 & 16.400 .000 \\
\hline $\begin{array}{l}\text { Lemari } 3 \\
\text { Pintu }\end{array}$ & 30 & 15 & $2 \mathrm{~m}^{3}$ & 4.000 .000 & 8.000 .000 \\
\hline Daun Pintu & 50 & 10 & $5 \mathrm{~m}^{3}$ & 4.000 .000 & 20.000 .000 \\
\hline Jendela & 100 & 60 & $1,6 \mathrm{~m}^{3}$ & 4.000 .000 & 6.400 .000 \\
\hline Kunsen & 150 & 25 & $6 \mathrm{~m}^{3}$ & 4.000 .000 & 24.000 .000 \\
\hline Bupet & 10 & 8 & $1,25 \mathrm{~m}^{3}$ & 4.000 .000 & 5.000 .000 \\
\hline Jumlah & 1.460 & & $61,73 \mathrm{~m}^{3}$ & & 246.920 .000 \\
\hline
\end{tabular}

Table 4.10. Badan Baku Per Unit 


\begin{tabular}{lccr}
\hline \multicolumn{1}{c}{ Produk } & $\begin{array}{c}\text { Unit yang } \\
\text { dihasilkan } \\
\text { untuk } 1 \mathrm{~m}^{3} \\
\text { kayu }\end{array}$ & $\begin{array}{c}\text { Harga per } \\
\mathrm{m}^{3}\end{array}$ & $\begin{array}{c}\text { Harga per } \\
\text { unit yang } \\
\text { dihasilkan }\end{array}$ \\
\hline $\begin{array}{l}\text { Kursi } \\
\text { kuliah }\end{array}$ & 45 & 4.000 .000 & 88.889 \\
$\begin{array}{l}\text { Meja } \\
\text { guru }\end{array}$ & 35 & 4.000 .000 & 114.285 \\
$\begin{array}{l}\text { Kursi } \\
\text { guru }\end{array}$ & 45 & 4.000 .000 & 88.889 \\
$\begin{array}{l}\text { Meja } \\
\text { sekolah }\end{array}$ & 40 & 4.000 .000 & 100.000 \\
$\begin{array}{l}\text { Kursi } \\
\text { sekolah }\end{array}$ & 50 & 4.000 .000 & 80.000 \\
$\begin{array}{l}\text { Lemari 1 } \\
\text { pintu }\end{array}$ & 20 & 4.000 .000 & 200.000 \\
$\begin{array}{l}\text { Lemari } 2 \\
\text { pintu }\end{array}$ & 17 & 4.000 .000 & 235.294 \\
$\begin{array}{l}\text { Lemari } 3 \\
\text { pintu }\end{array}$ & 15 & 4.000 .000 & 266.666 \\
$\begin{array}{l}\text { Daun } \\
\text { pintu }\end{array}$ & 10 & 4.000 .000 & 400.000 \\
$\begin{array}{l}\text { Jendela } \\
\text { Kunsen } \\
\text { Bupet }\end{array}$ & 60 & 4.000 .000 & 66.666 \\
\hline \multicolumn{1}{|l}{ Jumlah biaya bahan Baku per unit } & $\mathbf{2 . 3 0 0 . 6 8 9}$ \\
\hline
\end{tabular}

\section{b. Tenaga Kerja Langsung}

Seluruh tenaga kerja di industry ini hanya mempekerjakan laki-laki saja. Jam kerja untuk setiap harinya di sesuaikan dengan produk yang diproduksi, akan tetapi maksimal jam kerja industry ini adalah 9 jam per hari. Pemberian gaji untuk masing-masing tenaga kerja disesuaikan dengan produk yang telah diproduksi.

Table 4.11. Biaya Tenaga Kerja Langsung

\begin{tabular}{llcrr}
\hline No. & \multicolumn{1}{c}{ Jenis } & Volume & \multicolumn{1}{c}{$\begin{array}{c}\text { Biaya } \\
\text { perunit }\end{array}$} \\
\hline 1. & Bupet & 10 & 800.000 & Jumlah \\
2. & Jendela & 100 & 30.0000 & 3.000 .000 \\
3. & Kunsen & 150 & 100.000 & 1.500 .000 \\
4. & Kursi Kuliah & 300 & 60.000 & 18.000 .000 \\
4. & Kursi+Meja Sekolah & 500 & 70.000 & 35.000 .000 \\
5. & Lemari 1 Pintu & 200 & 400.000 & 80.000 .000 \\
6. & Lemari 2 Pintu & 70 & 500.000 & 35.000 .000 \\
7. & Lemari 3 Pintu & 30 & 600.000 & 18.000 .000 \\
8. & Meja + Kursi Guru & 150 & 150.000 & 22.500 .000 \\
9. & Pintu & 50 & 200.000 & 10.000 .000 \\
& & & 2.910 .000 & $\mathbf{2 3 1 . 0 0 0 . 0 0 0}$ \\
\hline
\end{tabular}

c. Overhead Pabrik

1. Bahan Baku Tidak Langsung

d.

e. Fggf

f. Fvfv

g.

Kegiatan-kegiatan amal atau sosial merupakan bentuk dari penilaian psikologis \& ekonomi. Pada penilaian psikologis, kegiatan sosial dianggap sebagai bentuk perbaikan diri, sedangkan pada penilaian ekonomi, kegiaan sosial merupakan sebuah balasan atas apa yang akan mereka lakukan nanti atau dengan kata lain timbal balik keuntungan (Thagard \& Nisbett, 1983). Thagard \& Nisbett berpendapat bahwa kegiatan sosial dilakukan untuk mendapatkan kepuasan batin saat melakukan sesuatu yang dianggap baik, serta dengan kegiatan yang mereka lakukan tersebut akan mendapat balasan secara langsung dari manusia itu sendiri (dunia) seperti pujian, balasan bantuan serta ucapan terima kasih, maupun balasa dari tuhan (akhirat). Namun dalam tulisan ini penulis melihat bahwa kedua balasan tersebut dapat didefinisikan sebagai surga, dimana balasan serta penilaian seseorang di dunia sebagai balasan dari surga dunia, serta harapan mendapatkan amal oleh tuhan sebagai keinginan mendapatkan surge di akhirat. Sehingga itulah yang mendorong anak muda menjadikan kegiatan-kegiatan amal di dalam komunitasnya sebagai salah satu gaya hidup untuk mendapatkan surga.

Melihat bagaimana kegiatan sosial dipan\&g sebagai kegiatan yang bersifat dunia \& akhirat, pada awalnya kegiatan sosial bermunculan dari institusi-institusi keagamaan diseluruh dunia. Tercatat pada gerakan organisasi sosial di Inggris \& Amerika, bahwa kegiatan amal dilakukan oleh Negara untuk mensejahterakan rakyat \& pekerja sosial, namun dibalik itu Negara masih menggunakan nama institusi keagamaan dikarenakan kegiatan amal dianggap merupakan aktivitas agama antara manusia \& tuhan (Leiby, 1984). Begitu pula data-data yang didapatkan oleh penulis setelah melakukan wawancara kepada berbagai informan. Kegiatan-kegiatan amal yang mereka lakukan saat ini merupakan bentuk pembayaran kebaikan tuhan kepada mereka, karena mereka tidak termasuk dalam golongan orang-orang yang mereka bantu karena membutuhkan pertolongan.

Dalam tulisan ini, penulis melaku-kan pengamatan \& wawancara kepada tiga narasumber yaitu SB (22), IK (18) \& WL (23). Kegiatankegiatan sosial yang mereka lakukan merupakan kegiatan "wajib" yang harus mereka laksananakan minimal sehari dalam seminggu. Akhirnya mereka memilih untuk "hidup" di tengah komunitas sosial, salah satunya agat mereka dapat menambah pengalaman serta lebih "up to date" atau tidak ketinggalan zaman seperti anak muda lainnya.

Kegiatan sosial yang telah mereka lakukan selama beberapa tahun lalu, sejak tiga, lima bahkan sejak tujuh tahun lalu merupkan kegiatan sampingan di tengah aktivitas utama yang mereka lakukan, seperti sebagai pelajar, mahasiswa \& pekerja kantoran. Salah satu narasumber, WL menceritakan bahwa kegiatan ini sudah sejak tiga tahun lalu dia geluti dengan berbagai komunitas sosial lainnya. Kini, WL telah memiliki tiga komunitas sosial. 
Sebelum bekerja, WL mulai aktif kegiatan sosial di akhir-akhir perkuliahannya saat mengunjungi beberapa daerah di Lombok untuk mengajar \& membuat sekolah bagi anak-anak di suatu wilayah yang kurang mampu. Dorongan WL untuk hadir di tengah masyarakat bukan semata-mata untuk mengejar surga akhirat, melainkan kepuasan diri. Salah satu kepuasan yang dia dapatkan ketika dapat berbagi informasi \& berita di medsos kepada rekanrekannya sehingga daerah yang akan dia bantu menjadi dikenal \& turut menggerakkan anak muda lainnya di sekitar untuk menjadi relawan seperti dirinya. Namun, tidak jarang dia dikenal sebagai WL yang berjiwa sosial di kalangan rekan-rekan anak muda, penilaian tersebut sebagai suatu kepuasan "surga dunia" yang dia dapatkan.

Selain WL, ada juga IK yang sejak SMP (kini telah berkuliah) telah mengikuti kegiatan sosial di FAS. Bukan hanya kebahagiaan saat rekanrekannya menge-nal dia sebagai IK yang berjiwa sosial saja, melainkan karena sering mengupdate foto \& jargon-jargon sosial, IK sering dipuji oleh rekan - rekannya, kepuasan - kepuasan seperti itulah yang salah satunya didapatkan, sehingga dapat dikenal oleh sekitar. Walaupun di balik itu, IK juga berharap mendapatkan amal atas apa yang dia lakukan, dimana dia bercerita kepada penulis bahwa dia sering melakukan kesalahan di dunia, sehingga harapan bahwa ada kesimbangan saat dia terjun ke dunia sosial. Contohya saat mengungkapkan dia masih jarang solat, atau secara general dia masih jarang beribadah sesuai tuntunan agamanya. Maka, kegiatan sosial sianggap sebagai solusi, sehingga ada harapan Tuhan akan mengampuni dosa-dosanya ketika membantu sekitar.

Melihat perilaku IK, penulis meru-juk pada argumen Sarah Moore. Moore menjelaskan bahwa perilaku masyarakat yang melakukan kegiatan amal merupakan ketakutan mereka terhadap sang Pencipta, dimana kegiatan-kegiatan tersebut merupakan tabungan masa depan atau disebut sebagai asuransi pemakaman (Moore, 2008: 137148) sama seperti yang dijelaskan oleh IK, bahwa kegiatan-kegiatan amal yang dia lakukan sebagai bentuk rasa syukur \& terima kasih kepada sang pencipta karena segala yang telah diberikan kepa\&ya, selain itu dia dapat "mendiskon" dosadosanya sehingga ketika melakukan kebaikan dengan kegiatan sosial, harapa untuk diampuni oleh Tuhan pun datang. Atau dengan kata lain, IK melakukan penenangan diri melalui kegiatan sosial yang dia lakukan.

Saat ini IK yang aktif di kegiatan-kegiatan sosial di Sumbawa merasa bahagia dapat merasakan surga yang ada di dunia bahkan telah mendapatkan kehidupan yang layak serta menyiapkan tabungantabungan untuk masa depan di akhirat. Seperti unkapan Moore di atas IK \& narasumber lainnya seperti SB juga merasa jika dengan membantu orang-orang saat ini, maka mereka akan diberikan balasan \& bantuan oleh sang pencipta kedepannya. Bahkan kegiatan tersebut dapat menyeimbangkan segala kesalahan-kesalahan yang pernah mereka lakukan di dunia.

Seperti yang disampaikan IK, SB juga aktif di kegiatan yang sama dengan IK di FAS. SB beranggapan bahwa fenomena kegiatan amal tidak terlepas dari kegiatan-kegiatan yang dilakuakan anak muda untuk mencari kebahagiaan. SB saat ini bekerja sebagai freelancer di berbagai perkantoran di Lombok maupun di Sumbawa. SB merasa kegiatan sosial sebagai bentuk persiapan untuk menyiapkan masa depan yang lebih baik dengan pembuktian dari orang-orang yang menyaksikan facebook yang dia miliki. Seperti dalam tulisannya Motivations for Charity in Early Modern, menjelaskan setiap kehidupan manusia akan selalu ada orang yang butuh pertolongan, maka dengan memberikan pertolongan, kita juga akan menolong diri kita dari persiapan-persiapan pada masa akan datang (Dinan dalam Safley, 2002:175).

SB beranggapan bahwa kegiatan-kegiatan amal selama ini dia lakukan untuk masa depannya yang lebih baik, harapan-harapan tersebut dijadikan sebuah tabung-an masa depan sehingga orang-orang yang butuh pertolongan yang mereka lakukan saat ini tidak akan terjadi pada mereka \& saudara, selain itu juga bantuan yang dilakukan diharapkan akan ada orang yang datang membantu jika mereka membutuhkan pertolongan nantinya. Bantuan (balasan) tidak harus dating dari seseorang yang mereka tolong saat ini, namun bisa dating dari siapapun, terlebih dengan medsos, orang-orang mengetahui dirinya sebagai SB yang berjiwa sosial $\&$ hadir di berbagai komunitas sosial di masyarakat. Dari tulisan di atas, penulis melihat bahwa kegiatankegiatan sosial disekitar anak muda saat ini dijadikan ajang untuk mendapatkan keuntungan untuk diri mereka sendiri. Dengan melakukan kebaikan kepada sekitar, maka mereka telah mempersiapkan masa depan lebih baik, kedepannya jika mereka mendapatkan masalah maka mereka berharap dapat bantuan dari orang-orang, sebagaimana mereka melakukan kebaikan kepada orang lain.

Di dalam pembahasan ini, medsos menjadi "jalan" utama untuk mereka mendapatkan kedua surga tersebut. Dengan medsos orang-orang akan mengenal diri mereka sebagai si berjiwa sosial, selain itu harapan-harapan doa dari orang yang mereka bantu akan menjadikan mereka lebih dekat dengan surga akhirat. Melihat perilaku WL, IK \& SB dalam berkomunitas sosial di medsos juga sebagai bentuk gaya hidup untuk mendapatkan surga. Dengan medsos akan membantu mereka dalam memperkenalkan diri kepada masyarakat luas. Medsos berperan penting dalam mem-berikan informasi \& menampilkan ber-bagai macam kegiatan yang mereka lakukan. Tampilan-tampilan yang diberi-kan sebagai bentuk seperti yang 
dijelaskan oleh Sarah Moore dalam tulisannya tentang Simbolic Uses of The Ribbon, dimana menggunakan Ribbon atau tanda pita untuk melakukan kegiatan-kegiatan amal sebagai bentuk jati diri mereka untuk turut mendungkung (Moore, 2008. 58). Seperti ungkapan yang dilontarkan oleh WL, IK \& SB bahwa mereka sering menggantikan akun Facebook atau foto profil medsos sebagai bentuk dukungan atau bantuan untuk sekitar. Salah satu contohnya saat terjadi gempa bumi, banjir, anak-anak yang terkena sakit \& perlu bantuan kesehatan serta kegiatan-kegiatan sosial lainnya. Dengan aktivitas yang mereka lakukan, mereka telah melakukan tontonan kepada masyarakat, dengan harapan mendapatkan surga di dunia \& akhirat.

\section{PENUTUP}

\section{Kesimpulan}

Komunitas sosial yang digerakkan oleh anak muda kian marak berkembang di Sumbawa, terlebih anak muda-anak muda saat ini memanfaatkan medsos untuk mempromosikan kegiatannya. Perilaku-perilaku dalam bermedsos memperlihat-kan bahwa anak muda ingin menunjukkan dirinya sebagai pemilik tanggung jawab \& bukan anak-anak lagi. Di balik kegiatan sosial tersebut, anak muda menjadikan kegiatan sosial sebagai ajang gaya hidup \& tontonan kepada masyarkat sekitar, atau dengan kata lain mereka menunjukkan kebaikannya melalui medsos dengan tujuan mendapatkan surga. Surga di dunia dengan pembuktian oleh masyarakat sekitar, sedangkan surga di akhirat sebagai bentuk tabungan amal untuk kebaikan yang mereka lakukan sehingga mendapatkan ampunan atas dosa yang pernah mereka lakukan.

\section{REFERENSI}

Debord, Guy. 1998. Comment on The Society of The Spectacle. Verso: London.

Drew, Jesse. (2013). A Social History of Contemporary Democratic Media. Routledge: London.
Freud, Sigmunt. (1997). The Transformations of Puberty. Dalam Adolescence and Psychoanalysis: The Story and The History. Editor Maja Perret-Catipovic \& François Ladame. Karnaca Books: London.

Kementerian Perdagangan RI. (2014). Panduan Optimalisasi Media Sosial untuk Kementerian Perdagangan RI. Kementerian Perdagangan: Jakarta.

Korpijaakko, Maria Leena. (2015). Cracking Facebook : The Importance of Understanding Technology Based Communication

Legium Veteran Republik Indonesia. (1981). Naskah Pola Perjuangan Kemerdekaan Republik Indonesia Daerah Sumbawa Sejak 17 Agustus 1945 - 27 Desember 1949. Ba\& Pembina Pelestarian Jiwa Semangat Nilainilai 45: Sumbawa.

Leiby, James. 1984. Charity Organization Reconsidered. Dalam Jurnal Chicago: Social Service Review, Vol. 58, No. 4 Hal. 523538.

Moore, Sarah EH. 2008. Ribbon Culture: Charity, Compassion, and Public Awareness. Palgrave Macmillan. New York.

Safley, Thomas Max. 2002. The Reformation of Charity: The Secular and the Religious in Early Modern Poor Relief. Brill Academic Pulisher: Boston.

Thagard, Paul \& Nisbett, Richard E. 1983. Rationality and Charity. Dalam jurnal Chicago: Philosophy of Science, Vol. 50, No, Hal. 250-267.

\section{Internet}

Antaranews. 2015. Warga NTB Memilih Jadi TKI. http://antaranews.com. Diunduh pada 20 Maret 2016 16:44

Indonesiamengajar. 2015. Tentang Indonesia Mengajar. http://indonesiamengajar.org. Diunduh pada 28 Maret 2016. 08:48 wita.

Kominfo. 2015. Pengguna Internet di Indonesia 63 Juta Orang. https://kominfo.go.id. Diunduh pada 30 April 2016 06:54 